\title{
Die boek Openbaring - brandpunte in die teologiese debat
}

\author{
D A Viljoen \& Andries G van Aarde \\ Departement Nuwe-Testamentiese Wetenskap \\ Universiteit van Pretoria
}

\begin{abstract}
The Book of Revelation - current interests in the theological debate

This article argues that the insights of academic research conducted within the framework of the believing community are not limited exclusively to an academic debate, but have implications for the proclamation of the church. The article illustrates this by surveying the scholarly contributions of Elisabeth Schüssler Fiorenza and Frederick $J$ Murphy with regard to current popular interests in the Book of Revelation. It addresses issues such as genre, the interrelationship between history and eschatology, and authorship. The article aims to create an awareness of moralistic preaching and the misuse of Scripture.
\end{abstract}

\section{PROBLEEMSTELLING}

Met die eeuwisseling was doemprofesiez en toekomsvoorspellings onder die vaandel van kerklike verkondiging aan die orde van die dag. Die algemene en basiese veronderstelling dat die Bybel verskuilde kodes bevat met inligting oor gebeure wat in die moderne tyd verwag kan word, vind neerslag in popularistiese boeke wat ook onder Christene gewild is. Skrywers van sulke werke soos byvoorbeeld Hal Lindsey se boeke The late great planet earth en Wederkomskode vind veral die visioene in die Openbaring van Johannes as dié bron van toekomsvoorspellings. Murphy (1994:182) wys egter daarop dat daar 'n groot gaping bestaan tussen hierdie popularistiese werke en kritiese akademiese werk. 
Die invloedryke gewildheid van hierdie popularistiese werke, wat ook genoem kan word fundamentalistiese media-apokaliptisisme (Fiorenza 1989:1), kan vermoedelik teogeskryf word aan die feit dat dit maklike antwoorde bied op gelowiges se vrae te midde van die onsekerhede van hulle bestaan. Mense soek sekuriteit, en wat bekend is, bied dit onder andere omdat 'n mens jou dan ten minste daarop kan voorberei. Soekers na die sin van die lewe wil antwoorde hê.

Murphy (1994:206) vat die verhouding tussen popularistiese werke en kritiese akademiese arbeid as 'n probleemstelling pragtig saam: "Critical scholars find themselves at odds with the very presuppositions of many Christians who find Revelation meaningful today as specific predictions of our own time." Die vraag aan die kerk is of die kerk met 'n akademiese, kritiese arbeid die Bybel kan aktualiseer in die lewe van die gewone gelowige mens op soek na sekuriteit en die sin van die lewe. Is die kerk se waaksaamheid teen fundamentalisme en sentimentalisme nog proklamerend gerig op die gewone lewe van gelowiges te midde van hulle alledaagse worstelinge? Dien die teologiese debat van akademici ten opsigte van brandpunte in die navorsing op apokaliptiese literatuur alleen maar die universitêre akademiese milieu, of bied dit ook verkondigingsmoontlikhede by die eeuwisseling met die oog op die lewensbestaan van Christene?

Hierdie artikel ondersoek eksemplaries enkele brandpunte in die akademiese teologiese debat besonderlik op die terrein van die apokaliptiese boek Openbaring aan die hand van twee moderne teoloe, te wete Elisabeth Schüssler Fiorenza en Frederick J Murphy. In die lig van die probleemstelling sal gepoog word om die aktualiteit van die akademiese navorsing op Openbaring vir die kerklike verkondiging te bepaal.

\section{METODOLOGIE}

Aspekte. wat in hierdie artikel onder die vergrootglas kan kom, verteenwoordig twee oorhoofse sake, te wete 'n identifisering van resente brandpunte in die teologiese debat, en 'n ondersoek van 'n eksemplariese hantering van sodanige brandpunte deur 'n moderne teoloog. Vir hierdie doeleindes word gebruik gemaak van twee artikels deur Frederick J Murphy in Currents in Research Biblical Studies (1994) wat resente brandpunte identifiseer. Elisabeth Schussler Fiorenza se boek The Book of Revelation: Justice and judgement (Fiorenza 1989) dien as voorbeeld van 'n moderne teoloog se hantering 
van die debat. Fiorenza (1991) se model word toegelig deur 'n voorbeeld van haar eksegese van Open 10:1-15:4. Uit dié bondige ondersoek word dan 'n antwoord gewaag op die probleemstelling.

\section{APOKALIPTIEK EN OPENBARING - DIE DEBAT}

In 1970 het 'n boek deur Klaus Koch getiteld Ratlos vor der Apokalyptik akademiese arbeid op die apokaliptiek in die middeljare van ons eeu gekarakteriseer as ' $\mathrm{n}$ tydperk van ongemak met dié literatuursoort. Navorsing en artikels het merkbaar minder verskyn, maar in die afgelope twintig jaar het hernude belangstelling navorsing geprikkel (Murphy 1994:182). Navorsingsgroepe op die apokaliptiek het die resente akademiese arbeid op 'n indringende, ernstige en sistematiese koers van navorsing geplaas. Daarmee het die debat ook meer intensief geword.

\subsection{Apokaliptiek as genre}

"Genre" verwys na 'n groepering van tekste wat bepaalde karakteristieke eienskappe deel ten opsigte van inhoud, vorm en funksie. Dit is onderworpe aan dinamiese verandering vanwes interaksie tussen verskillende soorte genres (vgl Murphy 1994:150). Dat dit nie altyd so eenvoudig is om literatuur as genre te definieer nie, word duidelik met 'n studie van die apokaliptiek.

Tot en met Klaus Koch en Paul Hanson se werksdefinisies is die begrip "apokaliptiek" gebruik as 'n vae en komplekse amalgamasie van literêre vorms, religieuse idees, beelde, visioene en sosiale bewegings. Koch het in die sewentigerjare 'n onderskeid gemaak tussen apokalips as genre, en apokaliptiek as verwysend na 'n historiese beweging met 'n bepaalde wêreldbeeld. Hanson het die onderskeid verfyn: apokalips as verwysend na die genre, apokaliptiese eskatologie as religieuse perspektief en apokaliptisisme as die ideologie van 'n groep wat die wêreldbeeld van die apokalipse deel (Murphy 1994:148). Resente akademici onderskei tussen die literêre vorm apokalips, die wêreldbeeld apokaliptisisme en die sosiologie van apokaliptiese groepe (Murphy 1994:183).

Die invloedrykste definisie van die apokalips as genre kom uit die werk van die Apocalypse Group of the SBL Genres Project. In die definisie word gestel dat die 
apokalips 'n genre is wat bestaan uit openbaringsmatige literatuur met 'n narratiewe raamwerk. Die openbaring word bemiddel deur ' $n$ hemelse wese wat 'n transendente realiteit aan 'n menslike ontvanger bekend maak. Hierdie transendente realiteit is temporeel van aard in die belofte van eskatologiese verlossing, maar ook ruimtelik omdat dit 'n bonatuurlike wêreld betrek (Murphy 1994:183). Hierdie definisie plaas die klem op die inhoud en vorm van die genre, maar die funksie daarvan bly steeds 'n ope vraag. Moet die funksie van die genre apokalips gesoek word in die sosiale konteks daarvan, of in die teks self? Navorsingsresultate van die Seminar on Early Christian Apocalypticism of the Society of Biblical Literature het die insig na vore gebring dat 'n genre op verskillende wyses in verskillende sosiale kontekste betekenis kan verkry. Funksie en teks gaan hand aan hand (Murphy 1994:151-152).

Die definisies wat voorgestel is, laat steeds ruimte vir verskil. Alhoewel apokaliptiek breedweg omlyn is en reeds ' $n$ bepaalde koers aan navorsing gee, bly sekere debatspunte steeds akuut op die tafel van navorsers: Wat konstitueer die apokaliptiese genre? Hoe moet apokaliptiese eskatologie omskrywe word? Watter elemente omlyn 'n tipiese apokaliptiese wêreldbeeld? Watter sosiale fenomene kwalifiseer 'n groep of beweging as apokalipties (Murphy 1994:149)? Binne die raamwerk van hierdie debat is dit dus 'n moeilike uitdaging om die boek Openbaring sinvol te verstaan en uit te lê.

\subsection{Genre van Openbaring}

Murphy (1994:155) sê: "A complicating factor in discussions of genre is that apocalypses often incorporate elements of other genres or are themselves of mixed genre." Hierdie stelling karakteriseer een van die debatspunte wat nie nuut aan die moderne eeu is nie: Is Openbaring 'n apokalips of nie? Murphy (1994:185) verwys na 'n moderne teoloog, Linton, wat hierdie probleem in die negentigerjare erken as een van die sterk debatspunte: "Genre is a critical construct, a heuristic notion that offers an interpretative strategy. Some works are easily classified, others not. Works that are highly intertextual resist simple classification. Such is the case with Revelation."

Daarmee word die vraag gekompliseer. Tradisiekritiek met 'n klem op die identifisering en isolering van oorspronklike tradisies in 'n teks het grootliks bygedra tot die 
vraag of Openbaring as apokaliptiese literatuur, indien dit so aanvaar word, 'n Joodse of Christelike karakter het.

Gedurende die agtiende eeu het akademici hierdie vraag beantwoord deur 'n digotomie te stel tussen Joods-apokaliptiese taal en Christelik-teologiese inhoud (Fiorenza 1985:23). Daarmee het hulle die debat rondom apokaliptiese literatuur vereng tot ' $n$ redusering van die verbeeldingryke taal vạn Openbaring in 'n een-tot-een betekenis. Resente studies vra na die houdbaarheid van so 'n digotomie, waarskynlik ook onder invloed van die nuwere literere kritiek met die klem op die teks as 'n literêre eenheid. Soos Fiorenza (1985:25) dit stel: "Scholarship on this book is in the process of integrating the historical-critical and literary-critical paradigms into a new literary-historical paradigm of interpretation." Volgens haar kan slegs so 'n nuwe paradigma reg laat geskied aan die eie aard van sowel die simboliese taal van Openbaring as die historieskommunikatiewe situasie van die boek.

Gemeet aan die definisie van die Apocalypse Group of the Society of Biblical Literature Genres Project is Openbaring 'n apokalips. Die sterk visioenryke simboliese taal reflekteer 'n narratiewe raamwerk, bemiddeling van 'n openbaring deur 'n hemelse wese aan 'n menslike ontvanger (Johannes), en 'n transendente werklikheid wat eskatologiese verlossing beloof. Daarby karakteriseer Openb 1:1 wat volg onder die titel

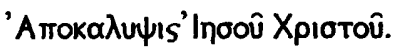

Een van die karaktereienskappe van die apokalips is pseudonimiteit wat veral algemeen was in die Hellenistiese tydperk (en groeibodem van die apokaliptiek). Dit ontbreek by Openbaring en word deur sommige as argument aanvaar om die apokaliptiese genre van Openbaring te bevraagteken (Murphy 1994:156). In Openb 1:3 word wat volg, ook 'n profesie genoem en Johannes verwys na homself as 'n getuie. Eksegete soos David Hill verstaan Johannes op grond daarvan meer soos 'n profeet van die $\mathrm{Ou}$ Testament. Johannes se funksie sou dan eerder dié van 'n interpreteerder van die $\mathrm{Ou}$ Testament in die lig van die Christus-gebeure wees (Fiorenza 1985:135). Openbaring se gebruik van die Ou Testament tesame met die swak Grieks vol van Hebraismes gee 'n sterk Joodse kleur aan die boek. 'n Eksegeet soos S Thompson vind die Grieks van Openbaring sterk beïnvloed deur die Ou Testament profete en maak derhalwe die skrifturilike agtergrond daarvan noodsaaklik om Openbaring te verstaan (Murphy 
1994:191). Daarmee word die karakter van Openbaring bevraagteken tot die vroegChristelike profetiese genre of Joodse apokaliptiek (Fiorenza 1985:136).

Murphy (1994:200-201) wys saam met Fiorenza (1985:135) daarop dat die Ou Testament op 'n bepaalde wyse gebruik word. Met die uitsondering van een direkte verwysing na 'n Ou-Testamentiese teks in Openbaring 15:3 word die Hebreeuse Bybel nooit aangehaal nie. Die verwysing in Open 15:3 is self ook nie literêr verbonde aan Eksodus 15 of Deuteronomium 32 nie, maar verteenwoordig slegs 'n amalgamasie van temas uit die Ou Testament. Johannes interpreteer nie die Ou Testament nie, maar gebruik sy gedagtekonsepte, taal, beelde en frases om 'n eie teologiese argument ter tafel te stel. Fiorenza (1985:136) stel dit dat die skrywer van Openbaring sy lokus van openbaring vind in sy eie histories-teologiese situasie, en nie in dié van die Ou Testament profete nie. Johannes se Christologie wat gebaseer is op Jesus se dood en opstanding, en die gevolg dat die eskatologiese eindtyd aangebreek het, maak dit vir Johannes dan ook moontlik om pseudonimiteit te ontduik (Fiorenza 1985:138). Die kerklike konteks van Openbaring veronderstel volgens Fiorenza ook dat die rol van presbiters nog nie so hoog aangeskrewe was nie, maar dat profetiese leierskap wel hoog geag was. Johannes maak dus aanspraak op sy eie profetiese gesag in opposisie tot ander profetiese groepe sodat pseudonimiteit nie belangrik was nie (Fiorenza 1985:151).

Fiorenza (1985:138) verkies 'n standpunt wat nie 'n keuse maak tussen of profeties of apokalipties nie, maar wat ruimte laat vir 'n profetiese verkondiging van die openbaring van Jesus Christus se eskatologiese koms in die taal van die apokaliptiek. Die skrywer kon moontlik ook 'n religieuse ervaring gehad het op grond waarvan die profeties-paranetiese verkondiging plaasvind in die taal van die apokaliptiek. Soos Murphy (1994:157) dit stel: "After all, scribes could also be mystics."

'n Eensydige beklemtoning van die Joods-apokaliptiese karakter van die boek Openbaring laat die misverstand dikwels posvat dat die boek 'n produk is van die JoodsPalestynse Christendom. Studies ten opsigte van die Pauliniese en post-Pauliniese teologie is daarom min (Fiorenza 1985:146). Die teologiese konteks van Klein-Asie veronderstel 'n bekendheid met die Pauliniese en post-Pauliniese teologie. Johannes verstaan sy profetiese roeping soortgelyk aan dié van Paulus. Dit blyk uit onder andere die feit dat slegs Openbaring en die Pauliniese en post-Pauliniese tradisies die vol titel 
Die openbaring van Jesus Christus bevat. Gal 1:15-16 verwys waarskynlik na Paulus se roeping, volgens Fiorenza (1985:150), as 'n visioenêre ervaring soortgelyk aan dié van Johannes. Ook die Pauliniese briefvorm word tot 'n sekere mate gedeel met die vorm van Openbaring. Joods-apokaliptiese tradisies is waarskynlik aan Paulus bemiddel deur vroeg-Christelike profete as in ag geneem word dat 'n paranetiese patroon wat ons in Openbaring vind, sowel as in Pauliniese en post-Pauliniese tradisies, ook voorkom in 1 Pet 4:7 en 17 (Fiorenza 1985:147). Dit suggereer onder andere die bestaan van 'n vroee profeties-apokaliptiese groep wat Christelike apokaliptiese-eskatologiese tradisies geinterpreteer en uitgebrei het (Fiorenza 1985:152).

Openbaring is ' $n$ uitdrukking van vroeg-Christelike profesie in die taalraamwerk van 'n Joodse apokalips met 'n eie teologie wat eskatologies gerig is op die vroegChristelike gemeentes in Klein-Asie.

\subsection{Geskiedenis en eskatologie}

Hoe word die geskiedenis in Openbaring beskou? Watter rol vervul die eskatologie? Wat is die fundamentele hermeneutiese sleutel vir die verstaan van Openbaring?

Fiorenza (1985:46) beskou die hermeneutiese sleutel van navorsing in die verlede as die konsep van geskiedenis. Die vooronderstelling was dan dat die skrywer se vraag na die betekenis van geskiedenis ook die struktuur van sy boek sou bepaal. Dit het hulle in die struktuur van die boek laat soek na 'n logiese volgorde of dialektiese lineêre ontwikkeling van die geskiedenis. Die benadering bekend as die kirchengeschichtliche benadering het Openbaring beskou as "a picture of the things that are to come until the end of history from the viewpoint of the Church of Christ" (Fiorenza 1985:36). Die endgeschichtliche benadering met die eschata as verstaansleutel het Openbaring beskou as 'n beskrywing van die volgorde van werklike gebeure wat na die einde van die wêreld se bestaan verwag kan word. Ook die zeitgeschichtliche benadering wil uit Openbaring 'n konsekutiewe geskiedenis van die primitiewe kerk aflei. Eksponente van hierdie benadering is onder andere M Hopkins en A Feuillet (kyk Fiorenza 1985:37-38). Gebeure uit die verlede tyd word aangebied as toekomstige gebeure. Pseudonimiteit dien hierdie vooruitdatering (Fiorenza 1985:41) en vorm die vooronderstellings van 'n apokaliptiese geskiedenis se uitleg. Omdat hierdie twee sake in Openbaring ontbreek, 
weerhou dit enige temporeel-ontwikkelende interpretasie van die boek. "The author does not aim to present a historical sequence; nor does he seek to justify and deduce the future from history. Rather he understands his book as a prophecy for the present which receives its justification from the future, that is, from the coming of Christ (22:20)" (Fiorenza 1985:42). Die gevaar van hierdie benadering is dat dit die teologiese relevansie van die boek vir ons tyd negeer.

Die geschichtsphilosophishe benadering soek na die betekenis van die geskiedenis deur 'n basiese teologiese waarheid agter die gebeure van die geskiedenis te probeer navors. Die visioenêr beleef geskiedenis dus as 'n proses van kritiese waarhede in die algemeen en as 'n paradigma van sy of haar eie geskiedenis. Die beelde en visioene van Openbaring word dus tipologies gesien van wat "agter" die geskiedenis van die wêreld skuil. E Lohmeyer het volgens Fiorenza (1985:43) tereg die kritiek teen hierdie benadering uitgespreek. Volgens Lohmeyer het die skrywer van Openbaring nie die betekenis van die geskiedenis probeer navors nie, maar die apokaliptiese oordeel van God oor die wêreld. Lohmeyer se werk het die eskatologie in fokus gebring met die geloofsgemeenskap as verwysingspunt. Die grense van tyd word daardeur deurbreek, sodat die eskatologiese toekoms reeds vir die gelowiges aangebreek het. T Holz kritiseer Lohmeyer se benadering as dat dit die temporele karakter van die geloofsgemeenskap en die wêreld negeer. Hy ontwikkel 'n Christelike heilsgeschichtliche interpretasie van Openbaring wat die dialektiese spanning tussen die "alreeds" en die "nog nie" van die verlossing beklemtoon. Die konsep van geskiedenis bied 'n eenheid of sentrum in hierdie dialektiek. Fiorenza (1985:45) erken die positiewe in hierdie ontwikkeling, maar bevraagteken die konsep van die geskiedenis as sentrale middelpunt in die dialektiek van die geloof. Die "alreeds" van die verlossing is nie histories teenwoordig nie, maar eskatologies sodat ook die geloofsgemeenskap steeds onderworpe bly aan die oordeel van God (met verwysing na Openb 3:5).

Vir Fiorenza (1985:45) bly die vraag akuut: "how does the 'already' relate to the 'not yet' in Rev. so that the temporal and wordly character of the Church is not dimished by considering the eschatological future as a mere manifestation or uncovering of what has already been realized in the present?" Sy deel resente navorsing wat die eskatologie as hermeneutiese sleutel tot 'n verstaan van die boek neem. Murphy (1994:203) 
karakteriseer Fiorenza se werk dan ook in hierdie verstaansraamwerk: Openbaring is vir haar 'n profeties-apokaliptiese interpretasie van die geskiedenis in die lig van die eskatologiese tyd wat begin het met die dood en opstanding van Jesus Christus. Verlossing in Openbaring is vir haar gebaseer op die Joodse idees van Eksodus en bevryding. Deur die aanbieding van 'n alternatiewe simboliese universum waarin God regeer, bied Openbaring bevryding van Romeinse onderdrukking sonder om die dialektiek van die "alreeds-nog nie" op te hef. Met verwysing na Openb 6:9-11 beklemtoon Fiorenza (1985:47-48) dat Openbaring se skrywer nie soek na die betekenis van die gekiedenis en 'n temporele volgorde daarin nie, maar die betekenis van die huidige situasie vir die geloofsgemeenskap. In die lig van die totale boek se samestelling is die eskatologiese laaste oordeel van God en die eskatologiese verlossing die klimaks van die boek. Soos wat God nou in die hemel heers, sal God in die wêreld heers. Die persoon van Jesus Christus bind die hede met die verlede en die toekoms. Teenoor die Joodse apokaliptiese literatuur probeer Openbaring betekenis gee aan die lydende geloofsgemeenskap met 'n verstaan van die hede vanaf die perspektief van die eskatologiese koms of inbreek van God se koninkryk in die wêreld, en nie met 'n verwysing na 'n goddelike plan met die geskiedenis nie.

Die struktuur van Optnbaring is derhalwe volgens Fiorenza (1985:51) bepaal deur die teologiese fokuspunt van die skrywer wat sy vind in die eskatologiese realiteit van God se koninkryk (1985:56). Dit is die hooftema van die boek soos gereflekteer deur die himne in Openb 11:15-19. "The generative center of Rev. is not the course of history but the experience of the Christian community in the christologically qualified end time" (Fiorenza:1985:3) Die skrywer interpreteer profeties die konkrete situasie van Christene in Klein-Asiě as die kort rukkie voor die einde. Daarom is die samestelling van Openbaring nie lineêr-progressief nie, maar kaleidoskopies-siklies. "The text moves forward but also revisits persons and actions, viewing them from new perspectives. This structure reflects the already-not yet character of the work's eschatology" (Murphy 1994:191-192). Die briefvorm in Openbaring kwalifiseer die profetiese interesse van die skrywer met die huidige situasie van die geloofsgemeenskap as 'n eskatologiese interesse nie net in die begin nie, maar ook die middelstuk en einde van die boek. Die totale boek is dus tematies gerig op eskatologiese oordeel en verlossing. 
Die belydenismatige formule van Openb 1:5-6, met die klem op die verlossing deur Christus se bloed en die gevolglike verklaring van die geloofsgemeenskap as God se koninkryk en priesters, kan egter binne die eskatologiese raamwerk van Openbaring aanleiding gee tot 'n entoesiastiese misverstand: dié van 'n gerealiseerde eskatologie wat die "nog nie" ophef (Fiorenza 1985:73). Openb 5:9-10 is 'n himniese, teologiese redaksie van die skrywer wat 'n antagonisties-etiese sowel as eskatologiese verstaan van verlossing implementeer om hierdie misverstand tee te werk (Fiorenza 1985:75). Die skrywer van Openbaring beskryf verlossing in sosio-politieke terme analoog aan die verlossing van Israel uit Egipte. Die Christelike gemeenskap is die alternatief tot die Romeinse Ryk deurdat God reeds daar as universele Regeerder erken word. Daarin skuil die "alreeds" van die eskatologie. Die "nog nie" van die eskatologie bestaan daarin dat alleen diegene wat getrou bly aan die stryd teen die goddelose, deel sal verkry aan die eskatologiese Koninkryk van God. So beklemtoon die skrywer van Openbaring die imperatief wat moet volg op die indikatief van die Christelike bestaan (Fiorenza 1985:76). Dit gebeur deur die eskatologiese karakter van die verlossing.

\subsection{Die outeurskap van Openbaring}

Wie was verantwoordelik vir Openbaring? Wat is die verhouding tussen die Evangelie van Johannes en Openbaring? Tradisioneel is in die teologie vanaf die laat tweede eeu tot en met die moderne kritiese studie dikwels aanvaar dat die outeurs van beide dieselfde was (Fiorenza 1985:86). In die moderne debat word dit nie meer so geredelik aanvaar nie (Murphy 1994:185). Stilistiese en teologiese verskille is baie te midde van die navolgbare linguistiese en teologiese affiniteite.

Die opkoms van die Johannese skoolhipotese het aan die outeurskapsvraag 'n nuwe dimensie gegee met die teorie dat 'n groep van leerlinge van die apostel Johannes verantwoordelik was vir die redaksionele verwerking en opskrywe van die apostel se werke. Hierdie hipotese wil veral die interne bewyse in die twee tekste aanwend om nie net die ooreenkomste te verklaar nie, maar ook teenstrydighede. Dit dien ook om die kerklike tradisie rondom die vraagstuk te legitimeer, en voorsien 'n eksegeties-teologiese kontinuitteit tussen die Johannese literatuur.

Fiorenza verstaan volgens Murphy (1994:186) die coreenkomste tussen Openbaring en die Evangelie van Johannes as die invloed van 'n interaksie tussen ver- 
skillende skole of groeperings in Klein-Asiě, naamlik 'n Johannese groep, Pauliniese groep en Openbaringgroep. Openbaring staan nader aan die Pauliniese groep as aan die Johannese groep. Fiorenza (1985:94) beklemtoon dan ook die feit dat Openbaring 'n groter affiniteit het vir Pauliniese terminologie. Christologiese titels soos die logos-titel verskil in die twee geskrifte (Openbaring en die Evangelie van Johannes) ten opsigte van teologiese en tradisionele kontekste: in die Evangelie van Johannes karakteriseer die titel 'n pre-eksistente figuur sonder om die titel verder te ontwikkel, terwyl die titel in Openbaring een van vier name is wat die "wederkomende Christus" (die sg paroesieChristus) teologies omskryf. Ook eskatologiese metafore word teologies verskillend aangewend. Dit laat Fiorenza die metodologiese vraag stel of dit moontlik is om uit literêre en formele affiniteite af te lei dat twee geskrifte soos Openbaring en die Evangelie van Johannes aan dieselfde outeurs toegeskryf kan word. Kon 'n skrywer nie toegang gehad het tot verskillende Christelike tradisies sonder om aan 'n bepaalde kring te behoort het nie ? Tesame met Conzelman se waarneming dat Efese die sentrum was van die Pauliniese skool, vra sy of Openbaring nie groter toegang tot die Pauliniese skool kon gehad het as die Johannese skool nie (Fiorenza 1985:101). Die Johannese en Pauliniese trekke in Openbaring dien as getuienis van so 'n hipotese dat die skrywer toegang tot sodanige tradisies kon gehad het. Die feit dat hy sy boek in die raamwerk van 'n brief gegiet het, dui in die opinie van Fiorenza (1985:107) aan dat “...the author understands his book not only as a prophetic letter in general, but also specifically as a circular, authoritative pastoral letter and patterned it after the already traditional Pauline letter form."

Die familiariteit van die skrywer van Johannes met profeties-apokaliptiese tradisies laat die suggestie dat Openbaring die werk kan wees van 'n lid van 'n vroegChristelike profeties-apokaliptiese skool eerder as die Johannese skool (Fiorenza 1985:106). Bewyse dat hy ook moontlik 'n leier van so 'n skool kon wees, vind Fiorenza in die verwysing humin in Openb 22:16 wat 'n aanduiding kan wees dat die boek geadresseer is aan 'n spesiale groep van Gemeindepropheten. Die vraag bly egter oop vir. debat. 


\subsection{Johannes se opponente}

Dat die skrywer nader aan die Pauliniese tradisie staan, vind Fiorenza onder andere ook in die anti-assimilasie houding van Paulus, spesifiek sy opposisie tot die Korintiesgnostiese groepe of "entoesiaste" (Murphy 1994:186). Dit sluit aan by die debatspunt rondom die identiteit van die opponente van die skrywer van Johannes.

Die opponente van Johannes word genoem in die sewe briewe aan gemeentes in Klein-Asie. Die briewe aan die gemeentes van Efese en Pergamum maak melding van die Nikolaïete, die brief aan die gemeente van Pergamum meld die aanhangers van Bileam se leer, en die gemeente van Tiatira word vermaan teen Isebel. Die leer van hierdie drie groepe word deur 'n teologiese verklaring van hulle sonde op een lyn geplaas: hulle eet vleis wat aan afgode geoffer was en lewe sedeloos. Num 25:2 ('n drukfout gee in Fiorenza se verwysing vers 12 aan) en 31:16 bied die teologiese agtergrond van hulle sonde (Fiorenza 1985:116). Alhoewel die Nikolaiete waarskynlik 'n rondreisende groep (profete?) was en die aanhangers van die leer van Bileam en Isebel aan die gemeenskappe van Pergamum en Tiatira behoort het, het hulle gemeenskaplik volgens Fiorenza (1985:116) 'n libertynse karakter aan hulle leer gedeel. Daarvolgens het hulle oor ware gnosis beskik ten opsigte van die wese van God of die Satan wat hulle bevry van die magte van wêreld sodat hulle lewenswyse uitdrukking gevind het in veral immoraliteit. Dit was 'n reaksie op hulle leefwêreld wat ekonomiese oorlewing beteken het deur middel van 'n sinkretisme met die imperiale Romeinse Ryk. Soos die opponente wat Paulus in sy briewe aan die Korintiers aanspreek, word by hierdie gnostiese opponente van Johannes 'n gerealiseerde eskatologie gevind. Dit is dan teen hierdie agtergrond dat Johannes reaksionêr skryf téén 'n entoesiastiese teologie wat werk met 'n gerealiseerde eskatologie. Paulus het sy teenstand teen 'n entoesiastiese teologie verwoord met die hulp van apokaliptiese teologie (Fiorenza 1985:120). In wese verwoord Johannes in Openbaring baie dieselfde gedagtepatrone as by Paulus: Christene het steeds 'n etiese verantwoordelikheid en deel nog nie in die hemelse liturgie en koningskap tot en met die aanbreek van die laaste oordeel nie. Hulle kan dus hulle priesterskap verloor (vg1 Fiorenza 1985:122). Die gawe van verlossing moet bewys word in die konkrete religieus-politieke situasie van elke dag. Sinkretisme is nie die antwoord nie, daarom wil die skrywer van Openbaring die gelowiges versterk in hulle geloof en teenstand teen die immoraliteit en mag van die imperiale Romeinse Ryk. Hy doen dit met behulp van 
apokaliptiese teologie en mitologiese taal (Fiorenza 1985:125). Johannes se teologie is nogtans 'n teologie in eie reg.

\subsection{Die struktuur van Openbaring}

Wat is die doel van die skrywer met Openbaring? Hierdie vraag hang ten nouste saam met die vraag na die histories-sosiale agtergrond van Openbaring, en die vorm wat hy as literêre strategie aan sy geskrif gegee het om te bereik wat hy wou.

Murphy (1994:191) beklemtoon die probleme om 'n logiese struktuur in die boek Openbaring te vind met sy stelling: "There are almost as many outlines of the book as there are interpreters." Repetisies en gedeeltes wat parallel in karakter is, kompliseer die vraagstuk. Bronnekritiek het die vraag probeer hanteer met 'n poging tot identifisering van oorspronklike materiaal wat bestaan uit Joodse sowel as Christelike tradisies. Daaruit probeer hulle die narratief orden in 'n logiese teologiese sisteem. Openbaring is in die visie van hierdie benadering die samestelling van verskillende bronne deur ' $n$ redaktor. Die hersieningsteorie veronderstel weer 'n oorspronklike teks wat volledig selfstandig is, maar herhaalde kere her-verwerk is tot die resente teks. Die fragmenteteorie wil nie soos die genoemde twee die teks herorden nie, maar wil die teenstrydighede in die teks verklaar aan die hand van verskillende tradisies wat die outeur gebruik het, maar aangepas het waar nodig om sy eie teologiese standpunte te stel (Fiorenza 1985: 160-163). Die meeste resente eksegete aanvaar egter nie meer hierdie tipe benaderings nie (Murphy 1994:191).

Komposisiekritiek bied 'n alternatiewe benadering wat klem plaas op die outeur se verwerking van tradisionele patrone en nuwe materiaal tot 'n nuwe betekenis en eenheid. Literêre tipes verander van formele karakteristieke tot nuwe funksies in 'n nuwe raamwerk (Fiorenza 1985:164). Fiorenza (1985:159) vind haarself gemakliker tuis binne hierdie teorie deurdat sy die komposisionele eenheid van Openbaring verstaan as 'n doelbewuste konstruksie soos bepaal deur sy teologiese konsep.

Literêre vorme wat die outeur van Openbaring gebruik het en met nuwe betekenisse gelaai het, sluit in aspekte soos himnes en mities-poetiese taal, profetiese aankondigings en woorde en beloftes van God, en die briefvorm. Watter literêre tipe die skrywer oorhoofs in gedagte gehad het, is moeilik om te bepaal. Alhoewel die boek, 
volgens byvoorbeeld Jeske, bedoel was om in 'n liturgiese vergadering gelees te word, aanvaar min eksegete dat die boek 'n Christelike ritueel of liturgie voorskryf (Murphy 1994:198). Himniese materiaal in die boek vul visioene in die boek aan as kommentaar, maar is eweneens nie bedoel as liturgiese elemente vir 'n Christelike ritueel nie. Fiorenza (1985:170) vind egter die briefvorm as 'n konstituerende element wat die gesag van sy werk as 'n profetiese verkondiging in apokaliptiese taal onderstreep.

Die ineengevlegde aanwending van tegnieke soos simbole wat groepe vorm, kruisverwysings, kontraste en tussenposes verbind die realiteit van die hede en die eskatologiese toekoms saam tot ' $n$ tematiese eenheid. Deur invoegings op die basis van 'n ABA struktuur verseker die skrywer hierdie tematiese eenheid. Na die verskyning van die sewe engele met die sewe trompette in Open 8:2 is daar ' $n$ invoeging van ' $n$ hemelse liturgie (Openb 8:3-5), gevolg deur die plae wat begin (Openb 8:6). Dit maak die verdeling van 'n teks moeilik: "The author does not divide the text into separate sections or parts, but joins units together by interweaving them with each other through the method of intercalation" (Fiorenza 1985:173). Saam met hierdie tegniek speel die patroon van sewe en die twee boekrolvisioene en Christologiese visioene in Open 1:1220 en 19:11-16 belangrike rolle as komposisionele tegnieke. Fiorenza (1985:175) dui die oppervlaktestruktuur van Openbaring in 'n konsentriese patroon soos volg aan:
A $\quad 1: 1-8$
B 1:9-3:22
C $\quad 4: 1-9: 21 ; 11: 15-19$
D 10:1-15:4
C' $\quad 15: 1,5-19: 10$
B' $^{\prime} \quad 19: 11-22: 9$
$A^{\prime} \quad 22: 10-22: 21$

Volgens hierdie skema is die sentrale aspek van die boek die profetiese rol en die profetiese interpretasie van die situasie van die geloofsgemeenskap. 


\subsection{Die funksie van Openbaring}

Watter doel het die skrywer van Openbaring met sy boek gehad en die vorm waarin hy dit gegiet het? Wat is die histories-sosiale agtergrond van die boek?

\subsubsection{Kensketsing van die problematiek}

Akademici stem in die resente navorsing veral oor twee sake saam: (1) Openbaring is 'n diskoers in 'n mities-poëtiese taal wat nie gereduseer kan word tot historiese referente, teologiese proposisies en kulturele waardes nie, en (2) daar is historiese referente, teologiese, pastorale en kulturele waardes in Openbaring wat interpretasie beìnvloed en ondersoek moet word (Murphy 1994:195). Apokalipse is geskryf as response op spesifieke historiese situasies, maar projekteer aardse worstelinge op 'n kosmiese skerm. Konkrete situasies word gesien in 'n groter konteks, daarom kan apokalipse ook in latere situasies nuwe betekenis verkry (Murphy 1994:170). 'n Onderskeid moet egter getref word tussen twee tipes simbole: simbole wat in 'n een-tot-een betekenis aangewend word soos in wetenskaplike diskoerse, en simbole wat 'n hele verskeidenheid van betekenisse kan oproep en nie uitgeput raak nie (Fiorenza 1985:183). Popularistiese werke wend die simbole van Openbaring veral aan in die eerste opsig met 'n redusering daarvan tot historiese referente soos byvoorbee', Adolf Hitler. Murphy (1994:171) beklemtoon egter dat so ' $n$ aanwending die apokaliptiese verbeelding en die krag van die genre laat verloor.

Die funksie van die apokalips is voorheen verstaan as 'n bemoediging en vertroosting van diegene in ' $n$ krisis. In baie gevalle is 'n krisisagtergrond nie altyd duidelik aanwysbaar nie. Die algemeen aanvaarde siening van 'n vervolging van Christene onder Domitianus as agtergond tot Openbaring word deur baie resente eksegete bevraagteken op grond van nuwe navorsing oor die regeringstydperk van hierdie Romein. Die outeur van Openbaring het volgens so 'n benadering sy omstandighede ervaar as 'n krisis en ander vari sy standpunt probeer oortuig. Yarbro Collins huldig in hierdie opsig die standpunt dat die skepping van 'n apokaliptiese simboliese universum 'n raamwerk skep vir menslike optredes en keuses. Deur die persepsies van sy gehoor te verander, kan die apokalips tot 'n nuwe bewussyn by sy gehoor lei wat keusevorming kan beïnvloed (Murphy 1994:171-172). 
Fiorenza (1985:187) beskou die taal van Openbaring as mities-poětiese taal ook as visioenêre retoriek. Haar onderskeid behels dat die poẽtiese werk verbeeldingryke ervaring wil stimuleer, terwyl die retoriese werk mense wil motiveer of oortuig ten opsigte van bepaalde keuses en optredes, dus 'n verandering in houding en bewussyn. Sy vind die retoriese situasie van Openbaring in 'n sosiale situasie wat letterlik getuig van armoede, ekonomiese isolasie, geweld en vervolging (Murphy 1994:187). So 'n retoriese situasie word gekarakteriseer deur dringendheid en nood (Fiorenza 1985:192). Openb 13 se beelde getuig van 'n situasie waarvan in Plinius se brief aan Trajanus gewag gemaak word: die imperiale kultus onder Domitianus het verwag dat hy as "Heer en God" aanbid moes word. Omdat die Christene geweier het deur Jesus Christus as "Heer en God" te bely, is hulle vervolg. So 'n ervaring van vervolging en ook ekonomiese isolasie omdat die Christene geweier het om te deel aan die afgodsoffers by byeenkomste van handelaarsgildes, het hulle geloof in Christus as die Heer uitgedaag en verskillende teologiese vrae opgeroep. Deur die konstruksie van 'n simboliese universum het Johannes gepoog om sy profetiese standpunt van die realiteit van God te handhaaf en Christene te help om hulle geloof te behou.

Murphy (1994:195-196) karakteriseer Fiorenza se benadering as 'n poging om die digotomie tussen eksegese en hermeneutiek te oorkom deur 'n retoriese kritisisme te gebruik wat navors hoe die aspekte van die teks en die wêreld wat dit skep, korreleer met die konkrete historiese, sosiale en religieuse situasie van die skrywer en sy gehoor, sowel as hoe moderne interpreteerders nuwe betekenis uit hulle eie retoriese situasie probeer skep. Alleen diegene wat honger na God se regverdigheid en oordeel kan volgens Fiorenza (1985:198) Openbaring verstaan. Waar 'n sosio-politieke religieuse spanning geskep word deur onderdrukking en vervolging, kan Openbaring 'n katarsis bied en dieselfde evokatiewe effek hê as wat deur die outeur gebied is aan 'n oorspronklike gehoor.

\subsubsection{Openbaring 10:1-15:4 as voorbeeld van Fiorenza se eksegetiese arbeid}

Soos in 3.6 daarop gewys is, vorm hierdie gedeelte die sentrale fokuspunt of wentelpunt van die boek Openbaring volgens Fiorenza se eksegese. In lyn met die boek Openbaring se algemene struktuur is ook hierdie gedeelte tematies gestruktureer en nie temporeel nie 
(Fiorenza 1985:55). Dit word gekarakteriseer as 'n profetiese woord gerig binne die omstandighede van die geloofsgemeenskap se vervolging (Fiorenza 1991:73). Hoofstuk 10:1-11:13 funksioneer as 'n invoeging voor die blaas van die laaste trompet, wat dit tematies verbind aan die voorafgaande gedeelte van die trompetreeks. Die visioene van hoofstuk 11-14 klimaktiseer in die hoofstuk 15:2-3, die himniese lofsang oor God se regverdige oordeel, en dien op sigself weer as 'n inleiding tot die laaste plaagreeks.

Fiorenza (1991:35) verdeel die gedeelte soos volg:

$\begin{array}{lll}\text { - } & 10: 1-11: 14 & \text { Profetiese roeping } \\ \text { - } & 12: 1-14: 5 & \text { Profetiese interpretasie } \\ \text { - } & 14: 6-15: 4 & \text { Eskatologiese verlossing }\end{array}$

\subsubsection{Hoofstuk 10:1-11:14}

Hierdie gedeel sentreer rondom die selfverstaan en taak van die Christelike visioenêr.

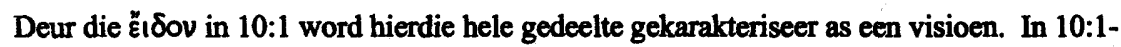
4 word die klein boekrol voorgestel in die hand van 'n engel. Die afwaartse beweging van die engel fokus die aandag op die aarde en die situasie aldaar van die geloofsgemeenskap. Die bevel om geheim te hou wat hy gesê het, is waarskynlik verwysend na die Sinoptiese tradisie dat God alleen die tyd en uur van die paroesie ken.

Dit word opgevolg deur die tweede subeenheid van 10:5-7 en die eed van die engel dat God se verborge bedoeling vervulling sal bereik. Dan 12:1-7 vorm moontlik

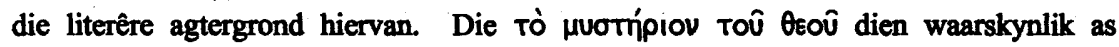
interpretasie van die sewe donderslae. By die blaas van die sewende trompet sal hierdie geheimenis van God bekend gemaak word. Dieselfde eskatologiese verlossing is hier die fokus as die van die laaste hoofstukke van Openbaring.

10:8-10 vorm die derde subeenheid waarvan Eseg 2:8-3:3 waarskynlik die literêre agtergrond vorm. Die eet van die rol simboliseer die soetheid van God se genade as dit soet proe, maar in die maag word dit bitter as simbool van die profetiese aankondiging van die dood vir diegene wat God teenstaan. 
Die vierde subeenheid is 10:11-11:2. Die profetiese aankondiging teen die konings en nasies as vyande van God se eiendom (aanduiding van die visioene wat sal volg op hoofstuk 11) moet opgevolg word deur 'n profetiese teken (met spore van Eseg 40:3) in die meting van die tempel. Dit moet eerder volgens Fiorenza (1991:76-77) simbolies-metafories verstaan word aangesien die tempel by die skrywe van Openbaring reeds vernietig was. Eskatologiese beskerming en versterking van die Christelike geloofsge-meenskap word waarskynlik daarmee bedoel - dit is die simboliese retoriek daarvan. Die heidene is uitgesluit wat hierdie saak betref. $\mathrm{Na}$ hierdie priesterlike

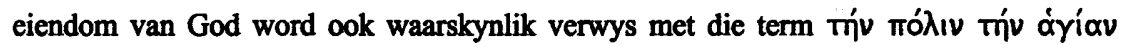
(Openb 11:2) aangesien die term "Jerusalem" in Openbaring slegs gebruik word as aanduiding van die nuwe Jerusalem. Dit is 'n "prophetic announcement of reversal" (Fiorenza 1991:77) waarvolgens die rolle omgekeer sal word: Die .Christelike geloofsgemeenskap wat nou ly onder vervolging, sal in die eskatologiese eindtyd beskerm word terwyl die vervolgers die vervolgdes sal word.

Die vyfde subeenheid is 11:3-12. Hier word simbolies-teologiese taal gebruik. Die twee getuies moet nie tot historiese referente gereduseer word nie, maar dien metafories as voorbeeld van die lot wat die Christelike gemeenskap tref by die uitleef van wat hulle verkondig. Sag 4:2 vorm moontlik die teologiese agtergrond waar die olyfboom en tempelkandelaar die koningskap van Serubbabel en hoepriesterskap van Josua simboliseer. Fiorenza (1991:78) vind in die verwysing na die magte van die twee getuies simboliese suggestie na Elia en Moses wat in die Joodse tradisie verwag word as eskatologiese profete. Die simboliese retoriek in vers 5-6 bevestig dat alhoewel Christene vervolg word, niemand hulle profetiese getuienis en oproep tot bekering sal kan keer nie. 11:7-12 se retoriese simboliek wys op die lot wat die Christene met hulle Heer Jesus Christus deel. Ook hulle sal die dood sterf onder hulle verkondiging, maar hulle sal die eskatologiese lewe beërf.

Die sesde subeenheid is 11:13 wat moontlik 'n antisipasie is op die aankondiging van 15:3-4 dat alle nasies voor God die knie sal buig. Fiorenza (1991:79) vind in die verwysing na nege-tiendes die retoriese simboliek van hoop vir die bekering van die heidene in lyn met die teologie van regverdige oordeel in Openbaring. 


\subsubsection{Hoofstuk 11:14-19}

In hierdie gedeelte sentreer dit om die ewige Koninkryk van God en Christus. Die tweede en derde weë-uitroepe verwys na die vyfde trompet wat opgevolg sal word met nog twee. Daardeur word 10:1-11:13 as 'n tussenvoeging binne die trompetreeks gekategoriseer. Die sewende trompet sal die laaste verlossing aankondig en funksioneer antisipatories tot die visioene van verlossing in Openb 21-22. Openb 11:17-18 is 'n eskatologiese oorwinningslied wat verlossing aankondig nie net vir die Christene nie, maar almal wat hulle bekeer het. Die doel van die plaagvisioene is nie vernietiging nie, maar die verlossing van die hele aarde van vernietigende magte.

\subsubsection{Hoofstuk 12:1-17}

Die mitologie van die hemelkoningin en die goddelike kind was internasionaal bekend in Johannes se tyd. In die Romeinse imperiale kultus vind ons dit met betrekking tot die godin Roma en die goddelike regeerder. As moeder van die godinne was Roma geregtig op haar eie tempel. Haar goddelike kind was beskou as die inkarnasie van die songod en redder van die wêreld. Johannes herinterpreteer waarskynlik hierdie mitologie in terme van Joodse verwagtinge. Die geboorte van die kind verwys volgens Fiorenza (1991:81) na Jesus Christus se troonsbestyging as die eersgeborene uit die dood. Die draak verwys in Joodse geskrifte dikwels na die vervolger of onderdrukker soos ook in Openbaring. Die vrou verwys na die Messiaanse geloofsgemeenskap wat in die tyd van vervolging deur God versorg word onder die simboliek van Israel se reis deur die woestyn. In die retoriese kritiek van Fiorenza (1991:82) bevestig dit dat die gelowiges die eskatologiese oorwinning behaal omdat hulle aan Jesus Christus vasgehou het selfs in die aangesig van die dood.

\subsubsection{Hoofstuk 12:18-14:5}

12:18 verbind die vorige gedeelte inleidend met hierdie deel wat as ' $n$ uitbeiding figureer op die oorlog van die draak teen die nakomelinge van die vrou. Die gedeelte volg die ABA patroon: 13:1-10 met die opkoms van die dier uit die see, 13:11-18 as die opkoms van die dier uit die aarde, en 14:1-5 as die opkoms van die Lam op Sion. 
In 13:1-10 word die mag van die imperiale Romeinse Ryk profeties ontmasker. Die see figureer geografies met Rome op die oorkanste kuslyn van waar die prokonsul Efese jaarliks besoek het. Mitologies simboliseer die see chaos en boosheid. Indien Dan 7 as teologiese agtergrond gebruik word, simboliseer die dier totale dominansie en ontmenslikende en onderdrukkende heerskappy van alle politieke magte. Daarby dien die dier as 'n parodiese spieel van die Lam wat geslag is en die dood oorwin het, waarskynlik as verwysend na die Nero-legende. Die volgelinge van die dier kom ook uit alle nasies en volkere. Die profetiese ontmaskering van die dier stel die retoriese situasie van 'n keuse: of vir God of vir Satan. In 13:11-18 word die imperiale kultus profeties ontmasker. Die funksie van die tweede dier word uitgespel as spreekbuis van die eerste dier. Hy wil die wêreld cortuig om die dier, Satan, te aanbid en so 'n kultiese gemeenskap teenstrydig aan die Christelike gemeenskap te vestig. Hy doen dit eerstens deur wonderwerke, duidelik antiteties tot die twee profetiese getuies. Die tegnologie het volgens Fiorenza (1991:85) in die antieke wêreld bestaan om aan beelde "lewe" te gee deur hulle te laat "praat". Die beelde het egter ook 'n publieke funksie vervul deurdat burgers en provinsies hulle lojaliteit aan Rome bewys het deur voor 'n kultiese beeld te buig. Tweedens word die volgelinge van die dier gekarakteriseer deur 'n merk op die regterarm en voorkop. Dit verwys na die ekonomiese en politieke onderdrukking onder die Romeine. Die Romeinse munt het die afbeelding van die heerser gedra en was noodsaaklik vir handel. Dit verwys waarskynlik na ekonomiese isolasie uit die handelaarsgildes omdat die Christene geweier het om te deel aan die afgodsoffers by hulle feesvieringe. Die betekenis van die 666 is onduidelik en het waarskynlik ook 'n ekonomiese impak gehad. "Revelation's notion of ultimate evil is best understood today as systemic evil and structural sin" (Fiorenza 1991:87).

\subsubsection{Hoofstuk 14:1-5}

Die visioen van die 144000 is 'n antitetiese visioen op dié van die draak en die twee diere, en kontinueer die motiewe van die vorige gedeelte. Die jukstaposisie van hierdie gedeelte met dié van die anti-goddelike magte dien as retoriek: om die gehoor van Openbaring te motiveer om hulle keuse vir God te maak, aangesien slegs diegene wat die Lam se merk dra, sal deel aan die eskatologiese Koninkryk van God (Fiorenza 1985:189). 
Die beeld van die $144000 \mathrm{kan}$ nie tot 'n een-tot-een betekenis gereduseer word nie. Die totale mensheid word geroep tot diens aan God, en die 144000 figureer simbolies as die eerstelinge van die bekeerdes of dienaars van God. Hulle etiese lewenspraktyk is die voorwaarde vir eskatologiese verlossing (Fiorenza 1985:191). Hierdie groep mense is dieselfde as die groep in 7:1-8 wat onder die eskatologiese beskerming van God staan (Fiorenza 1991:87).

Hierdie visioen konstitueer die eerste in 'n reeks van oordeelsvisioene. Vir hulle wat nie met die leuens van die imperiale kultus saamgegaan het nie, word verlossing in 'n eskatologiese sin aangekondig. Dit is ook hulle wat hulle nie met vroue besoedel het, 'n metafoor vir afgodediens en die praktyke wat daarmee gepaard gegaan het. Die visioen beskryf die alternatiewe gemeenskap in die midde van die imperiale kultus, waarvan laasgenoemde onder die eskatologiese oordeel van God kom.

\subsubsection{Hoofstuk 14:6-13}

Die triadiese oordeelsaankondiging in hierdie gedeelte antisipeer die reeks bakke met plae. Dit dien as 'n uitnodiging aan almal om God te dien deur die goeie boodskap wat die eerste engel uitroep. In tipiese profetiese woorde kondig die tweede engel die voltrekking van die oordeel oor Babilon aan. "Babilon" moet volgens Fiorenza (1991:89) nie in 'n een-tot-een betekenis verstaan word nie. 'n Verskeidenheid van skriftuurlike betekenisse kan deur hierdie simbool opgeroep word. Die derde engel se aankondiging funksioneer as 'n profetiese dreigement en retoriese vermaning wat standvastige weerstand teen die imperiale kultus en lojale volharding van die gelowiges vra. Retories gesproke bevestig hierdie gedeelte dat God nie die lewe en werk van die gelowiges sal vergeet nie, maar hulle dade sal beloon.

\subsubsection{Hoofstuk 14:14-20 (Die eskatologiese oes)}

Open 14:1-5 vind weerklank in die oestema van hierdie gedeelte. In die sentrum van hoofstuk 14 staan die "iemand soos die Seun van die Mens" wat die Christus van die paroesie simboliseer. Die eerste oes is op die aarde, wat nie net die 144000 uitverkorenes behels nie, maar ook die bekeerlinge uit al die nasies. Die tweede oesbeeld 
dui op die verskriklike oordeel van God wat die totale wêreld affekteer. Die retoriese krag van hierdie gedeelte moet nie as 'n beskrywing van 'n voorspelling gesien word nie, maar volgens Fiorenza (1991:91) as 'n evokatiewe waarskuwing wat weer eens 'n bepaalde bewussyn by sy gehoor wil skep ten einde 'n bepaalde keuse te stimuleer.

\subsubsection{Hoofstuk 15:1-4}

Vers 1 lei die visioene van die sewe engele met die sewe bakke in. Die draaipunt van die klein boekrolvisioene is die eskatologiese oorwinningslied van vers $2-4$, en funksioneer as 'n profetiese interpretasie van God se oordeel. Die Eksodusmotief van bevryding word duidelik aangewend wat tesame met ander simbole retories funksioneer om hoop te bring. Die Lied van Moses word die Lied van die Lam as 'n loflied aan God vir sy inisiatief in die verlossing. Die betekenis en doel van die visioene in die boek word deur hierdie lied volgens Fiorenza (1991:92) geïnterpreteer as universele oordeel en verlossing.

\section{NAVORSING: AKADEMIES EKSKLUSIEF OF KERKLIK IN- KLUSIEF?}

Elisabeth Shüssler Fiorenza se akademiese werk getuig van toegewyde en ernstige studie op 'n indringende, kritiese en sistematiese wyse. Haar formulering en argumentvoering is skerp en analities, maar tog deurdag en met 'n logiese onderbou. Sy laat die indruk dat haar navorsing nie net akademies van aard is nie, maar dit is ook 'n persoonlike geloofsworsteling.

Dat sy 'n liefde vir die boek Openbaring het, is duidelik - miskien omdat sy die behoefte van gewone gelowige mense verstaan om sin uit die lewe te kan maak? Sy doen moeite om die teologiese eie-aard van die boek Openbaring te beklemtoon. 'n Waarskuwing teen 'n misverstaan van die boek is implisiet in haar arbeid verweef; daarom die erns wat sy laat deurskemer om die teologiese eenheid van die boek in 'n eskatologiestematiese en nie chronologies-historiese verstaan nie, te respekteer. Die retoriese doel van die skrywer moet daarom in interpretasie van die boek tot sy reg kom, nie om mense deur ' $n$ vreestaktiek deur 'n eensydige klem op die oordeel in die boek tot bekering te 
motiveer nie, maar deur die balans te handhaaf wat in die verlossingstema ewe sterk op die voorgrond staan. Openbaring wil dus ook hoop skep in die verwarde wêreld van gewone gelowige mense. Haar akademiese arbeid waarsku juis teen die resente popularistiese werke wat eensydig net ellendes voorspel. Sy waarsku egter ook teen kerklike verkondiging wat geen erns maak met ernstige studie van die unieke karakter van Openbaring nie: "Rather than instill 'hunger and thirst for justice,' the symbolic action of Rev. therefore can perpetuate prejudice and injustice if it is not 'translated' into a contemporary 'rhetorical situation' to which it can be a 'fitting' response." (Fiorenza 1985:199)

Haar insigte kan in die prediking van die kerk waardevol gebruik word om mense die sin van hulle bestaan eskatologies vanuit God te vind. Gelowiges leef egter dikwels onbewustelik self ook met 'n gerealiseerde eskatologiese verstaan van hulle lewe. Prediking wat nie met die dialektiek van die "alreeds" en "nog nie" rekening hou wat uit Fiorenza se arbeid beklemtoon is nie, staan gevaar om in moralisme te verval. Fiorenza se werk beklemtoon die belang van 'n balans tussen die indikatief, imperatief en belofte van die evangelie. Die kerk ontdek sy taak aan die hand van hierdie ernstige akademiese werk tog nog steeds as 'n profetiese taak in die proklamasie van God se regverdige oordeel, maar ook genade wat eskatologies gekwalifiseer word. Die kerk se verkondiging begelei gelowiges vermanend tot 'n verstaan van hulle lewe. Dit is nie 'n toekomsvoorspelling as sodanig nie.

Akademiese arbeid kan dus, indien die insigte daanuit verantwoordelik gesoek word, steeds tot diens van die kerklike verkondiging bly. Dit stel parameters waarbinne verantwoordelike prediking kan geskied, maar skep ook 'n bewussyn van gevaarlike tendense en die altyd sluimerende gevaar van misbruik van die Bybel en moralisme wat dikwels sentimentalisties van aard is. Om "So sê die Here" te kan sê, is 'n worsteling met die Woord van God nodig, solank akademiese arbeid ook nederig onder gebed kan geskied. Daarsonder verval die akademiese arbeid gou in akademiese eksklusiwiteit. Gebed is die parameter van akademiese arbeid wat dit praktyk gebonde hou en sigself tot diens aan die kerklike verkondiging stel. 


\section{Literatuurverwysings}

Fiorenza, E S 1985. The Book of Revelation: Justice and judgement. Philadelphia: Fortress.

Fiorenza, E S 1991. Revelation: Vision of a just world. Minneapolis: Fortress.

Murphy, F J 1994. Apocalypsesand apocalypticism: The state of the question. Currents in Research: Biblical Studies 2, 147-179.

Murphy, F J 1994. The Book of Revelation. Currents in Research: Biblical Studies 2, 181-225. 